\title{
DIAS, Agemir de Carvalho. Sociologia da Religião: introdução às teorias sociológicas sobre o fenômeno religioso. São Paulo: Paulinas, 2012.
}

O autor da obra "Sociologia da Religião: introdução às teorias sociológicas sobre o fenômeno religioso" Prof. Dr. Agemir de Carvalho Dias é Mestre em Educação pela MACKENZIE e Doutor em História pela UFPR, possui larga experiência na docência na pesquisa cientifica.

O referido livro esta alocado na seção Pressupostos da Coleção temas do Ensino Religioso que é produzido pela editora Paulinas desde 2005, que tem como objetivo fundamentar epistemologicamente a disciplina de Ensino Religioso enquanto componente curricular, bem como subsidiar a formação dos professores que atuam com esta disciplina.

A obra se propõe a introduzir o leitor à sociologia da religião, levando o mesmo a conhecer os seus conceitos e autores. Seu principal diferencial é a associação entre teoria sociológica e história promovendo assim uma transposição didática do conteúdo acadêmico para o saber do cotidiano.

Logo na introdução da obra o autor já esclarece que os objetivos do livro são uma breve introdução às teorias sociológicas sobre o fenômeno religioso e destaca que a obra se propõe a analisar este fenômeno da religião partindo do surgimento da disciplina de sociologia.

No primeiro capítulo o autor apresenta as transformações que ocorrem com a religião no processo de transformação do sistema feudal para o sistema capitalista no ocidente, onde a religião deixou de ser referência para tanto para o ser humano como para a sociedade, transformando assim a religiosidade do mundo ocidental.

Já no segundo capítulo são analisadas as primeiras ideias a respeito da religião nessa nova sociedade secularizada, que também pode ser denominada de religião civil ou de um mundo sem religião.

No terceiro capítulo o autor busca nos clássicos da sociologia Karl Marx, Max Weber e Emile Durkhein fundamentos para analisar e reinterpretar esta sociedade.

Entrando no quarto capítulo o quarto se volta para a situação atual, para o mundo globalizado, onde as religiões deixam de ser locais para se globalizarem, ou seja, a religião também se globaliza e com isso temos o surgimento de outros problemas como o aumento do fundamentalismo. 
Já no quinto capítulo o autor apresenta como as mudanças ocorridas na sociedade moderna levaram a transformações na vida religiosa, uma dessas mudanças é a secularização, o pluralismo religioso, a ética religiosa, o trabalho religioso, dentre outras, que o autor fundamenta em Peter Berger, Pierre Bourdieu e Henri Desrosche.

Por fim no sexto capítulo o autor também procura destacar os autores brasileiros que se tornaram referência no estudo sociológico da religião Candido Procópio Ferreira de Camargo, Carlos Rodrigues Brandão e Roger Bastide.

A presente obra é academicamente relevante, tanto para a formação de cientistas da religião como também para a formação de teólogos, pastoralistas, catequistas, professores e leigos em geral, pois possui uma dimensão interdisciplinar e sistêmica que valorizam a formação integral da pessoa humana.

A referida obra também nos possibilita uma analise diacrônica e sincrônica sobre o fenômeno religioso pluralista da sociedade moderna, sob o olhar sociológico, que necessita de mais estudos e reflexões sobre seus conceitos e epistemologias, cujo autor se dispôs a realizar nesta obra.

Robson Stigar

Doutorando em Ciência da Religião - PUCSP. E-mail: <robsonstigar@hotmail.com>

Recebido em: 02/01/2017

Aprovado em: 23/10/2017

Correspondência para:

Robson Stigar

Rua Waldemar Loureiro Campos, 3751 - apto. 244

81720-180 Curitiba, PR, Brasil 